This item was submitted to Loughborough's Research Repository by the author.

Items in Figshare are protected by copyright, with all rights reserved, unless otherwise indicated.

\title{
From classical syndicalism to Spain's 15-M movement
}

PLEASE CITE THE PUBLISHED VERSION

https://books.emeraldinsight.com/page/detail/Protest-Technologies-and-Media-Revolutions/?

$\mathrm{K}=9781839826474$

\section{PUBLISHER}

Emerald Publishing Limited

VERSION

AM (Accepted Manuscript)

\section{PUBLISHER STATEMENT}

This book chapter was accepted for publication in the book Protest Technologies and Media Revolutions: The Longue Durée and the definitive published version is available at https://books.emeraldinsight.com/page/detail/Protest-Technologies-and-Media-Revolutions/? $\mathrm{K}=9781839826474$.

\section{LICENCE}

CC BY-NC-ND 4.0

\section{REPOSITORY RECORD}

Flesher-Fominaya, Cristina. 2020. "From Classical Syndicalism to Spain's 15-M Movement”. Loughborough University. https://hdl.handle.net/2134/11880918.v1. 
Not for circulation-do not cite

Accepted for Karatzogianni, Ferra, Schandorf (eds) Protest Technologies and Media

Revolutions: The Longue Durée Emerald, UK

\section{From classical syndicalism to Spain's 15-M movement}

\section{Cristina Flesher Fominaya}

In May 2011, activists and "ordinary citizens" filled the streets and squares of Spain demanding "Real Democracy Now!" and protesting against austerity cuts. They became known around the world as the "Indignados", and in Spain as simple the "!5-M" movement. The title of this chapter leads us to imagine that we can trace a chronological line or historical evolution from classical syndicalism to Spain's "15-M" or "Indignados" movement. It is true that within the studies of social movements in Europe there is a certain narrative that traces the evolution of contemporary progressive social movements from "origins" in the labour movement. The simplest version of the story goes something like this: the original social movement is the workers' movement or the labor movement. This movement is focused on demanding workers' rights and the redistribution of economic goods, it expresses a central social conflict between the working-class and the capitalist class, and it mobilizes the worker identity as political subject. From the 1960 s, we begin to see the emergence of new social conflicts and alongside and expressing these conflicts, new social movements that mobilize different political subjects and demands. From there, we enter into a scenario where mobilization takes on a more global character, fostered by globalization processes with a special emphasis on the advance of information and communication technologies, above all Internet and digital media. And from there we arrive at our contemporary scenario-- post global financial crisis-- with the movements of the squares and their demands for "real democracy now" and an end to austerity politics.

In reality it is not such a bad story and it does indeed capture some essential elements of social movement history in Europe and in Spain, which I will focus on later in this chapter. However, reality is more complex than simple stories allow. So in this chapter I am going to complicate this history somewhat and highlight some elements that might be of particular interest in the context of a book that takes as its subject the consequences of the Russian Revolution 100 years on.

In truth, in order to speak of the origins of progressive social movements, that is, those that seek to critique the status quo and improve the social conditions of a particular sector of the population, we need to begin before labor movements appear on the scene. Before the French Revolution (1789) we could already observe an early stage of an ideological struggle between 
Not for circulation-do not cite

Accepted for Karatzogianni, Ferra, Schandorf (eds) Protest Technologies and Media

Revolutions: The Longue Durée Emerald, UK

those who sought to change the social order and those who sought to conserve it. During the $18^{\text {th }}$ and $19^{\text {th }}$ centuries conservative thought became more systematized, but we also see the development of a number of different progressive ideological and philosophical currents such as anarchism, socialism and communism (Tormey 2020). All of these progressive political and philosophical traditions influenced the development of the labor movement, considered to be one of the maximum social forces in the development of industrial society. The labor movement is the result of a process of industrialization, the rise of capitalism, and the confrontation of interests between the workers and the capitalist class. The working-class finds its expression in three distinct but interrelated areas of activity: communist, socialist or social democratic political parties, unions, and the labor movement (Giugni and Grasso 2020). Within the study of social movements one of the most notable innovations of the labor movement was the development of the strike as a central part of its contentious action repertoire, a tactic that continues to be of great relevance to this day (Tilly and Wood 2009). From their origins, one of the central elements of the workers movements - independently of their particular ideological orientation- has been international solidarity, which is tied intrinsically to core understandings of equality and internationalism. With this simple fact, we can already see that the idea that social movements became "more global" in character in the 1990s is problematic.

In Europe, the struggle for workers' rights arose at the same time as initiatives to reform and expand political rights, although there is great variation between countries. For example, in England mobilizations for parliamentary reform were intertwined with demonstrations of strength on the part of workers, most notably in the Chartist movement (1836 to 1848). The movement did not directly achieve parliamentary reform - universal male suffrage did not become a reality until 1918 - yet over time almost all of the demands of the Chartists were incorporated into law. In Lyon France, in 1831, cries of "work or bread" were heard in prerevolutionary protests (Tilly and Wood 2009). In France, what we call "social movements" became consolidated as a political practice in parallel with the expansion of political rights. It is interesting, however, that the legalization of unions in 1884 did not radically transform forms of political protest, and it was only with the expansion of voluntary associations at the end of the 1880 s that protests began to consolidate themselves in the public life of the city of Lyon (Tilly 1986, Tilly and Wood 2009). Tilly (2009) reminds us that it was the 1 May 1890 that inaugurated a series of annual protests and demonstrations of workers in France in 
Not for circulation-do not cite

Accepted for Karatzogianni, Ferra, Schandorf (eds) Protest Technologies and Media

Revolutions: The Longue Durée Emerald, UK

multitudinous displays of international solidarity. Although the development of the labor movement and the expansion of political rights varies from country to country in Europe, in many countries the strikes and demonstrations of the workers movements play a central role in processes of democratization. Nevertheless, Tilly (2009) warns us that we cannot say that mobilization necessarily produces political rights or democracy. In some cases political rights precede the consolidation of social movements. In England (1884, 1918), the Nordic countries $(1898$ - 1920) and Italy $(1912,1919)$, for example, first we see the emergence of social movements and then we see democratic transition. On the other hand in France (1848, 1875 - 1877), Greece $(1864)$ and Portugal $(1911,1918)$ the process is reversed, first transition and then social movements. In Collier's classification (1999) on which Tilly is basing his analysis, only Spain appears in both columns: in 1868 for the precedence of democratic transitions, and in 1890 and 1931, when social movement activity precedes democratic transition. According to Tilly, what we can say is that, once we do see a consolidation of democratic rights, we can also observe the emergence of social movements. We can also say in general that the guarantees of the state in political rights has a great influence on the rise or decline of social movements, above all the rights to association and freedom of expression.

Leaving to one side these important details, let us return now to question some of the core assertions in the simple history that we began with. If it is true that the labor movement is and has been one of the most important movements in the history of social movements, it is not true to say that it is the only original movement. For example, we could point to the abolitionist movement which began in 1830 as an international movement of great impact and scope also closely tied to the development of human rights. Another example comes from the women's movements that incorporate diverse ideologies and that only in part demanded labor rights or focused on labor conflicts. Women's movements mobilized a different political subject - women - and this subject was, and is, more difficult to neatly define. Women also actively participated in the abolitionist movement and two of them, Elizabeth Cady Stanton and Lucretia Mott became leaders in the movement for women's rights. Of course, women also participated in the labor movement, fighting for the universal rights of workers, but also for justice and representation for women workers, a struggle that continues to this day, notably in areas such as the persistent wage gap and the so-called glass ceiling, (perhaps better named the cement ceiling given the continuing scant representation of women 
Not for circulation-do not cite

Accepted for Karatzogianni, Ferra, Schandorf (eds) Protest Technologies and Media

Revolutions: The Longue Durée Emerald, UK

in positions of power and responsibility in all spheres of public life). Here we can see processes of cross-contamination or influence from different movements, in which ideas about liberation and rights and freedoms flow between them and are carried by subjects with "multiple militancy" or belonging in different movements.

With these examples, we can see that dividing history neatly into a chronological sequence of labor movement, new social movements, and contemporary movements, does not correspond to reality (see also Cox and Flesher Fominaya 2013). However, there have been some broad changes in social movements' political cultures in particular historical periods. The $1960 \mathrm{~s}$ and 1970s was a period of important change in organizational forms and political cultures within social movements, at the same time as the so-called "new social movements" began to emerge. Here is where we can begin to see a distinction on the left (or within progressive politics) between those who continue to defend and justify formal organizational structures and representative forms and those who demand "new" more autonomous, horizontal, and expressive forms of collective action. According to Ingelhart (1977), these changes are due to what he called the silent revolution, a revolution of values that shifts from a system based on materialist values centered around socioeconomic needs, social order, and security, towards a system of post-material values centered on individual participation, personal emancipation, and the fulfillment of the individual's potential and capacities. This distinction between materialist and post-materialist values comes from Maslow $(1943,1954)$ and his hierarchy of needs: according to Maslow, human beings move upwards from basic needs which are materialist (physiological and the need for security) towards post-materialist needs (selffulfillment and the satisfaction of intellectual needs) once the needs of the bottom part of the pyramid are more or less satisfied.

The central features of this rupture between new social movements and the movements of the past is a shift in emphasis from central demands for a more just distribution of economic goods towards an emphasis on improving quality of life. Not only does this new imaginary of an improved quality of life not stem from a materialist vision, but it fundamentally questions the materialist and consumerist priorities of industrial society that are sustained by a political system based on representative democracy, which limits citizen participation and therefore also limits the individual's capacity to develop their full potential. Instead, these new movements call for new models of social organization based on direct democracy, mutual aid, solidarity, and cooperation (Pichardo, 1997:414). Within this context, autonomy and 
Not for circulation-do not cite

Accepted for Karatzogianni, Ferra, Schandorf (eds) Protest Technologies and Media

Revolutions: The Longue Durée Emerald, UK

questions of personal identity begin to gain a central place (Offe 1985, Giugni and Grasso 2020, Melucci 1994).

This process of change also transforms the dynamic of the central social conflicts: the conflict between worker and capital takes a step back and new conflicts emerge and find their expression in the so-called new social movements, centered around ecological, feminist, antimilitarist, and other claims. According to Inglehart's post material thesis, the massification of the educational system, the increase in social mobility, and economic growth and the expansion of the welfare state after the Second World War create the conditions for this cultural change to take place (Inglehart 1977, Tilly and Wood 2009, Giugni and Grasso 2020). This period also witnesses a transformation in the social bases of mobilization: in these new movements there is a strong component of activists that come from the middle classes rather than the working class.

The so-called new social movements were oriented around autonomy, individual expression, and profound critique of post-industrial society. The French sociologist Alan Touraine, one of the most notable analysts of 68 (Touraine 1971) and of the wave of new social movements, understood that these new movements represented a new class conflict between various political subjects (students, women, ecologists, workers etc.) who rejected the power of governments, large corporations, and mass media. The danger that the power of corporations pose to democracy is not a realization that emerged in this period for the first time.

Rutherford B. Hayes, the $19^{\text {th }}$ president of the United States between 1877 and 1881, wrote in his diary of the US government that: "this is a government of the people, by the people, and for the people no longer. It is a government of corporations, by corporations, and for corporations. (Diary, $11^{\text {th }}$ of March 1888). But if Hayes lamented the democratic deterioration of the institutions of government, the critics in the new social movements went beyond a critique of the institutions, alleging that it was the totality of elite interests that produced a conformist society that diminished creativity and the possibility of progressive social transformation. Theoretical expressions on these critiques include Marcuse's One Dimensional Man (2013 originally written in 1964) or Habermas' (1981) theory of the colonization of the life world by the system. Although most of these critiques centered on capitalism as the central problematic, for Touraine (1971) a central element of this new class conflict was the realization that the domination of the system exerted its influence independently of whether it stemmed from a socialist or capitalist democratic system. The 
Not for circulation-do not cite

Accepted for Karatzogianni, Ferra, Schandorf (eds) Protest Technologies and Media

Revolutions: The Longue Durée Emerald, UK

social movements of the time, which included feminism, indigenous rights, and environmentalism, among others, highlighted the fact that the forces of oppression did not only emanate from the mechanisms of capitalism but from any system based on a form of oppression, independent of its ideology and economic model: patriarchy and the destruction of the environment could be found in capitalist or communist systems. These realizations spurred a rejection or rethinking of classical Marxist tenets.

The expansion of movements seeking liberation from different starting points and mobilizing different identities were associated with the multiplication of associative spaces in civil society (Tilly and Wood 2009). In contrast to previous movements - according to Touraine these movements do not seek power and the control of institutions but rather to liberate citizens from all forms of domination. And although it is commonplace to focus on the differences between these new movements and the labor movement, for Touraine (1983) the most powerful example of the search for liberation from the dominant system was precisely a workers movement, the Solidarity movement in Poland, that did not seek to take power but rather to free society from the totalitarian domination of the Communist Party, signaling an important break with the past (Touraine 1983, Tilly and Wood 2009). In Czechoslovakia in 1989 , the general strike managed to achieve the support of three quarters of the population in a demand for freedom that brought an end to the authoritarian communist regime. These mobilizations, which brought together unions and diverse groups of intellectuals and civil society, extended throughout the region triggering a series of democratic transitions.

Therefore, the narrative that posits a chronological transition from workers movements to the emergence of new social movements can be critiqued, and has been critiqued, in at least two ways: on the one hand, it is obvious that in this period workers movements do not disappear or take a backseat, they continue to be an important force in mobilization during all the decades in consideration, and in some contexts they are the most important mobilizing force (Cruz 2015). On the other hand, as Calhoun (1995) argues, we can find identity-based movements mobilizing political subjects that are not workers prior to the emergence of new social movements: in the $19^{\text {th }}$ century we can find nationalist mobilizations (for example, the Hungarians who defend themselves against the Austrian Empire), mobilizations of women (for example, the Suffragettes) and religious movements (for example, German religious migrants such as the Amish), and on the other hand, within workers movements we can find demands for identity and for autonomy, traits that are usually associated with the so-called 
Not for circulation-do not cite

Accepted for Karatzogianni, Ferra, Schandorf (eds) Protest Technologies and Media

Revolutions: The Longue Durée Emerald, UK

new social movements. The labor movement was not the original nor the hegemonic movement of the $19^{\text {th }}$ century, nor was it a monolithic movement, there were many labor movements with different identities and imaginaries and which did not focus their central claim making around the economy or workers' rights exclusively (Calhoun 1995). To these two critiques we can also add another: within the new social movements (or at least in dialogue with them) we can find class criticism. For example, when middle-class women in the feminist mainstream movement demanded that women be able to integrate fully into the labor market and not be restricted to the home, working-class women reminded the movement that they had always worked outside the home (and within it).

Notwithstanding these critiques and recognizing their empirical validity, as I argued above what we can witness in this period is a significant transformation in the political cultures within social movements that begin to emerge in the 60 s and that continue to develop in a progressive way until today. I am referring here to the differences between logics of collective action- between what we could call the Institutional Left and Autonomous movements. Although many theorists have argued that the most important differences between the "old movements" (Institutional Left) and the "new movements" (Autonomous) reside in their social basis, their values, and even in their tactics (Giugni and Grasso in preparation, Pichardo 1997), I think that the most relevant differences lay in their political cultures or their praxis, which combines ideological elements and forms of practicing politics.

Autonomous social movements, however, do not arise at the margins of the Institutional Left but in great measure develop as an explicit reaction against the Institutional Left's organizing logics or praxis. It is therefore important to explain what these differences are and why they are relevant to understand the history of European social movements and the contemporary mobilizing context.

\section{Two logics of collective action in conflict}

One of the most interesting political currents of 1968 comes from a group called the Situationist International. This group of intellectuals and artists within the orbit of Marxist theory rejected the Leninist tendencies of Marxist political practice as a result of their progressive disillusionment with the Orthodox and bureaucratic tendencies of the Institutional Left (Firat and Kiryel 2011). They understood capitalism as a system that managed to sustain itself through its fostering of consumerism, itself animated by visions of the good life that 
Not for circulation-do not cite

Accepted for Karatzogianni, Ferra, Schandorf (eds) Protest Technologies and Media

Revolutions: The Longue Durée Emerald, UK

were circulated by mass media. Therefore, they understood the cultural sphere as an important scenario of direct political interventions that could break through the hegemonic ideas that sustained the capitalist system. This distanced them from the classical political practices of the Institutional Left: no longer were strikes and protest marches the key forms of mobilization. Rather they sought to manipulate the cultural codes that sustained the system, to cut the emotional cords that connected individuals and consumer capitalism, and to provoke a breakup in the romance that united them. Although very few activists today identify themselves as Situationists, many of them are inheritors of the influence of this political tradition, and flash mobs and culture jamming can be considered a direct example of this influence (Flesher Fominaya 2019). Nevertheless, the autonomous tradition of mobilization stems from a diverse family of influences including anarchism, autonomous variants of feminism, pacifism, environmental activism, and techno-politics and radical geek hacktivism . From their diverse points of view, all of them reject vertical and bureaucratic forms of collective action.

Between the Institutional Left in the autonomous Left we can see clearly opposing logics of collective action which can be resumed schematically (see Table 1.).

\begin{tabular}{|l|l|l|}
\hline & .Institutional Left & Autonomous Left \\
\hline
\end{tabular}


Not for circulation-do not cite

Accepted for Karatzogianni, Ferra, Schandorf (eds) Protest Technologies and Media Revolutions: The Longue Durée Emerald, UK

\begin{tabular}{|c|c|c|}
\hline Political Model & Representative & Participatory \\
\hline $\begin{array}{l}\text { Organizational } \\
\text { Structure }\end{array}$ & $\begin{array}{l}\text { Vertical with clear division of labor, } \\
\text { fixed roles and formal leadership }\end{array}$ & $\begin{array}{l}\text { Horizontal, without fixed roles or formal } \\
\text { leadership }\end{array}$ \\
\hline Decision Making Forms & $\begin{array}{l}\text { Voting, negotiations, consultas or } \\
\text { mandate }\end{array}$ & Consensus, Mandate \\
\hline Political Subject & Unitary/Primary (worker, member) & Multiple cross-cutting identities \\
\hline Ideological Base & Unitary/Explicit (e.g. socialist) & Heterogeneous/implicit (autonomous) \\
\hline $\begin{array}{l}\text { Legitimate Political } \\
\text { Actor }\end{array}$ & Collective/Party/Union & Individual acting within the collective \\
\hline Arena of Action & Public/institutional & Public and Private \\
\hline Means/Ends & Variable & Inseparable (prefigurative) \\
\hline Organizations & $\begin{array}{l}\text { Permanent, the goal is to grow and } \\
\text { sustain itself over time }\end{array}$ & $\begin{array}{l}\text { Non-permanent, longevity related to } \\
\text { usefulness }\end{array}$ \\
\hline
\end{tabular}


Not for circulation-do not cite

Accepted for Karatzogianni, Ferra, Schandorf (eds) Protest Technologies and Media

Revolutions: The Longue Durée Emerald, UK

Table 1: Fundamental differences in logics of collective action between the Institutional Left and the autonomous Left (adapted from Flesher Fominaya 2007).

For our purposes here the central differences reside in the way in which the members of each type of organization understand legitimate and desirable forms of organizing. In ideal-typical terms, for the Institutional Left, the central characteristics are formal structures, representative leadership, formal affiliation, bureaucratic and functional systems of operation, hierarchical structures of decision-making, all with a clear division of labor between fixed roles. For the autonomous left, the desirable characteristics are non-hierarchical structures, informal groups, no representation, fixed roles, or formal membership, and connected between themselves in flexible and informal networks (Flesher Fominaya 2007). If the organizational model of the Institutional Left has dominated historically, the autonomous forms of organization have become more widespread in recent years, facilitated -according to some -by the development of digital and social media communication.

In the process of professionalization and formalization of the labor movement it is clear that unions have played a key role. So much so that often we do not even distinguish between the labor movement and its expression in the diverse unions that represent it. This is important for our purposes here because the large and established unions have organizational forms that are formal, representative, and hierarchical. This representative function is often tied to a particular sector. Trade union relations with leftist parties (who also organize in a vertical and bureaucratic fashion) influence the development of a movement culture that is also oriented towards hierarchical, bureaucratic, and representative frameworks, all of which are closely tied to their efficacy and legitimacy as political actors. But that which lends political legitimacy to some, is precisely that which is delegitimizing for others, since these characteristics reproduce the very hierarchies that autonomous movements seek to eliminate in order to advance toward a society that is truly egalitarian and free of oppression. Therefore, these differences are not just organizational preferences, they are important 
Not for circulation-do not cite

Accepted for Karatzogianni, Ferra, Schandorf (eds) Protest Technologies and Media

Revolutions: The Longue Durée Emerald, UK

ideological differences that are expressed through different forms of praxis. These preferences are not random but fundamental.

These differences in political culture with reference to the organizing logics of collective action help us to understand the difficulties that these actors face when they attempt to create alliances across their differences, despite their close agreement with respect to the object of critique or the problem that needs to be solved. For example, in the global justice movement (or the movement of global resistance) there was an important tension between the Institutional Left and the autonomous Left despite the fact that there were important alliances between actors (Flesher Fominaya 2014). It is also important to stress that this is an ideal typical distinction, an analytical construct that represents a much more complex reality. Between these two forms of organizational logic we can find specific organizations and political groups that combine elements of both tendencies in a hybrid form.

So what does all this have to do with Spain's 15-M movement? As of the early 2000's there was an increase in the legitimacy of autonomous forms of mobilization within political spaces that are associated with the global justice movement and which culminated in the 15M movement in Spain, a movement that- in its origins at least -rejects most strongly representative forms and bureaucratic structures. The vision of "real democracy now" that was demanded by the activists in the plazas of Spain is based on a vision of direct democracy without intermediaries in which all citizens can participate in the decisions that affect their lives. This vision is not new, it was present in 68. However, the context has changed, and in the 15-M this vision is not presented as a utopian alternative but rather as a demand that is strongly tied to the material realities and suffering of the population in a post crisis scenario. The 15-M movement can also be distinguished from earlier forms of mobilization in its desire to rescue democratic institutions for the citizenry (Flesher Fominaya 2015). It is a demand that fell on deaf ears within the political classes, but that penetrated the citizens' consciousness to an astonishing degree: one year after 15-M 2011, surveys indicate that $80 \%$ of the population agreed with the central demands of the movement (Sampedro and Lobera 2014; Flesher Fominaya 2017). The consequences of this movement continues to be feltparadoxically, given the autonomous character of the initial mobilizations - most visibly in 
Not for circulation-do not cite

Accepted for Karatzogianni, Ferra, Schandorf (eds) Protest Technologies and Media

Revolutions: The Longue Durée Emerald, UK

the institutional arena, with the most clear examples being the municipalist movements (for example, Barcelona en Comú, Ahora Madrid, Más Madrid) and Podemos.

\section{Trade Unions and 15-M}

Despite its great impact, one of the criticisms that is made of $15-\mathrm{M}$ is that it has not managed to bring labor conflicts to the fore, and has had much more success in highlighting the consequences of the crisis, such as evictions. The great social problem of mass evictions following the collapse of the housing bubble has garnered a lot of attention due to the mobilization of movements such as the Platform for those Affected by Mortgages (PAH) (Flesher Fominaya 2015), but mobilization centered around labor conflicts have not been as visible. The truth is that hyper flexible capitalism has not only displaced workers but has also thrown trade unions off kilter. In a scenario in which so many workers are precariousworking with temporary contracts or without contracts at all, most of whom do not belong to a particular sector, many of whom do not even work directly for corporations but rather for a subcontracted agency that does not pay for benefits, pensions, and holidays- the classical union model has become obsolete for many workers. In this scenario strike tactics also become much more difficult to organize.

In the context of labour mobilizations today, (and leaving aside the existence of precarious work in the past) the political subject that is mobilized -the worker-has also changed. The precarious political subject is different from the worker political subject, given that work is something that rarely appears in their lives. With luck, work appears once in a while but in ephemerous forms that do not permit the development of a coherent worker identity. In its place, some theorists speak of a precarious identity, characterized by the impossibility of constructing a life project in the long-term, a condition that provokes anxiety and other ills, but which also offers the possibility of developing creativity, solidarity, and collective action in the face of this existential crisis (Precarias a la Deriva 2004). With regard to the nature of contemporary labor, academics agree on two tendencies: the increasingly precarious nature of work and temporary contracts in the last 40 years (Ikeler 2012, Kalleberg 2011; Standing 2011; Weil 2014), and that the expansion of precarious labor goes hand-in-hand with neoliberal politics and the decline of trade unionism (Ikeler 2012).

In Spain, the large trade unions have denounced the problem of precarious labor and its particular impact on young workers, but it is difficult for them to represent these workers due 
Not for circulation-do not cite

Accepted for Karatzogianni, Ferra, Schandorf (eds) Protest Technologies and Media

Revolutions: The Longue Durée Emerald, UK

to the organizing logics of trade unions themselves which has not managed to adapt to the changes in the nature of contemporary capitalism and continues to be organized within particular companies and particular sectors. On the other hand, precariousness has also become more widespread within corporations that employ workers full-time, a situation that has facilitated the development of solidarity between precarious workers according to some studies (Ikeler 2018). What this shows is that class consciousness is not limited to the industrial or traditional working class but can also be the basis of new worker mobilizations in the contemporary context of precarious labor.

The complexities of the contemporary scenario made the relationship between the 15-M movement and the larger and more established trade unions a difficult one. Younger precarious workers and students did not see the trade unions as being able to represent their interests, a reality which also contributed to a feeling that it was necessary to move beyond the left/right political framework. The complicity of the larger trade unions with the labor reforms of the government also contributed to the critical stance of many activists in the 15M movement. Despite this, some trade unions have played a very important role in recent mobilizations. The general strike of 14 November of 2012 was primarily mobilized by the two largest trade unions (CCOO and UGT) who managed to integrate the participation of other European trade unions and a historical transnational strike. For its parts, the Andalusian trade union of workers (SAT) played an important role in the organization of the Marches of Dignity. The SAT also differentiates itself from other more institutional trade unions in its use of nonviolent civil disobedience such as the occupation and expropriation of food and school supplies. The SAT recovers a long tradition of the occupation of land in Andalusia by anarchist trade unions at the end of the $19^{\text {th }}$ century. When the assemblies of the $15-\mathrm{M}$ movement began to lose members many Andalusian activists began to participate in the SAT.

The 15-M movement also directly influenced the development of the Citizen Tides, some of which clearly combine trade union elements with elements of autonomous social movements, and which in many cases have labor conflicts at their center, such as the green tide (related to the educational sector) and the white tide (related to the health sector) (Sanchez 2013), but which also appeal to universal rights such as education and healthcare.

Although it is true that there is a rather ambiguous relationship between trade unions and autonomous social movements after 15-M, in the context of the global financial crisis the 
Not for circulation-do not cite

Accepted for Karatzogianni, Ferra, Schandorf (eds) Protest Technologies and Media

Revolutions: The Longue Durée Emerald, UK

clear division between materialist and post-materialist values that Inglehart (1977) pointed to disappears. Somehow we seem to have gone back to the beginning of the history of social movements, where the cries of "work or bread" mingled with demands for political rights. On the one hand, student mobilizations that precede 15-M and continue after it highlight the commodification of university studies and of students at the same time as they face a panorama in which earning a living in a dignified way becomes increasingly difficult. The struggles against the Bologna plan of university reform led to an awareness among some students of the necessity and possibility of mobilizing not only students, but youth in general as a political subject. This is where the group Youth without Future, whose slogan "no house, no job, no pension, no fear" prepared the terrain for the later demands of the 15-M Indignados (Iglesias Turrión 2015, Juventud sin Futuro 2011). There is a clear discursive connection between "education is not for sale" (a Bologna slogan) and the 15-M slogan "we are not merchandise in hands of politicians and bankers". On the other hand, with the Gag Law and the criminalization of protest (Flesher Fominaya 2014b), with political interference in juridical processes, and the use of the courts to resolve political conflicts, we can see that it is still as necessary as it was for those protesters in Revolutionary France to demand basic democratic rights, such as the right to assembly and freedom of expression and the separation of powers.

In the current moment (2019), we are facing a complex panorama for political action where the struggle for democratic rights and a social welfare state that takes care of its citizens' essential needs confronts a set of economic and political interests that represents an increasingly powerful but diminishing number of individuals (according to Oxfam $1 \%$ of the global population holds $87 \%$ of its wealth).

The data shows clearly that inequality has advanced at an alarming rate (Keeley 2015; OECD 2018). In this context, distinguishing between materialist and post-materialist values becomes an almost meaningless exercise: the well-being that post materialism seeks, the expression of individual identity, the economy that guarantees freedom becomes inconceivable without the satisfaction of the basic needs that grant dignity and quality of life to every human being. Defending the right to a dignified life is impossible in the absence of political rights that guarantee the freedom of protest and critique. This is something that those worker protesters of the $19^{\text {th }}$ century understood, it is something that the $15-\mathrm{M}$ protesters of 2011 called our 
Not for circulation-do not cite

Accepted for Karatzogianni, Ferra, Schandorf (eds) Protest Technologies and Media

Revolutions: The Longue Durée Emerald, UK

attention to, and it is something that we need to be aware of today, because not only the future but the present is at stake.

\section{References}

Cruz, Rafael. 2015. Protestar En España 1900-2013. Madrid: Alianza Editorial.

Collier, Ruth Berins. 1999. Paths toward Democracy. New York: Cambridge University Press

della Porta, Donatella (ed.). 2007. “The Global Justice Movement: An Introduction.” Pp. 1-28 in Donatella della Porta (ed.), The Global Justice Movement: Cross-National and Transnational Perspectives. Boulder, CO: Paradigm.

Firat, B. Ö. and Kuryel, A. (eds) (2011) Cultural Activism (Amsterdam: Rodopi Bv Editions).

Flesher Fominaya, Cristina, and Laurence Cox (eds.) 2013. Understanding European Movements: New Social Movements, Global Justice Struggles, Anti-Austerity Protest. London: Routledge.

Flesher Fominaya, Cristina. 2007. "Autonomous Movements and the Institutional Left: Two Approaches in Tension in Madrid's Anti-Globalization Network." South European Society and Politics. https://doi.org/10.1080/13608740701495202.

—.2014. Social Movements and Globalization: How Protests, Occupations and Uprisings Are Changing the World. London: Palgrave Macmillan. (2014b). Put a Gag on it: Spain's criminalization of 15-M. Red Pepper Magazine. Issue 196: 19.

2015. “Debunking Spontaneity: Spain's 15-M/ Indignados as Autonomous Movement." Social Movement Studies 14 (2): 142-63.

https://doi.org/10.1080/14742837.2014.945075. 
Not for circulation-do not cite

Accepted for Karatzogianni, Ferra, Schandorf (eds) Protest Technologies and Media

Revolutions: The Longue Durée Emerald, UK

Housing in Spain's PAH Movement." South European Society and Politics.

https://doi.org/10.1080/13608746.2015.1058216.

. 2017. "European Anti-Austerity and pro-Democracy Protests in the Wake of the

Global Financial Crisis." Social Movement Studies 16 (1).

https://doi.org/10.1080/14742837.2016.1256193.

Giugni, M y M. Grasso (2020) "Nothing Is Lost, Nothing Is Created, Everything Is Transformed": From Labor Movements to Anti-Austerity Protests. In Flesher Fominaya, C. and Feenstra, R. (Eds) The Routledge Handbook of Contemporary European Social Movements. London: Routledge.

Habermas, Jürgen. 1981. The Theory of Communicative Action. Cambridge: Polity Press.

Iglesias Turrión, Pablo. 2015. “Sin Casa, Sin Curro, Sin Pensión, Sin Miedo. La Juventud Del 15-M.” ACME: An International Journal for Critical Geographies 14 (1). [Okanagan University College, Dept. of Geography]: 30-41.

https://ojs.unbc.ca/index.php/acme/article/view/1132.

Ikeler, P. (2018). Precarity's Prospect: Contingent Control and Union Renewal in the Retail Sector. Critical Sociology. https://doi.org/10.1177/0896920517749706

Inglehart, Ronald. 1977. The Silent Revolution: Changing Values and Political Styles among Western Publics. Princeton, NJ: Princeton University Press.

Juventud Sin Futuro (JSF). 2011. Juventud Sin Futuro. Barcelona: Icaria.

http://www.icariaeditorial.com/pdf_libros/Juventud sin futuro.pdf.

Kalleberg, Arne L. 2011. Good Jobs, Bad Jobs: The Rise of Polarized and Precarious Employment Systems in the United States, 1970s to 2000s. New York: Russell Sage.

Keeley, B. (2015), Income Inequality: The Gap between Rich and Poor, OECD Insights, OECD Publishing, Paris, https://doi.org/10.1787/9789264246010-en.

Marcuse, H. 2013. One-Dimensional Man: Studies in the Ideology of Advanced Industrial Society. London: Routledge. https://www.taylorfrancis.com/books/9781134438808.

Maslow, A. H. (1943). A Theory of Human Motivation. Psychological Review, $50(4), 370-96$. 
Not for circulation-do not cite

Accepted for Karatzogianni, Ferra, Schandorf (eds) Protest Technologies and Media

Revolutions: The Longue Durée Emerald, UK

Maslow, A. H. (1954). Motivation and personality. New York: Harper and Row.

McAdam, Doug, Sidney Tarrow, and Charles Tilly. 2001. Dynamics of Contention.

Cambridge: Cambridge University Press.

Melucci, Alberto. 1994. "A strange kind of newness: What's new in new social movements."

in E Larana, Hank Johnston and JR Gusfield (eds.) New Social Movements: From Ideology to Identity. Philadelphia: Temple University Press.

OECD 2018 “Inequality" http://www.oecd.org/social/inequality.htm

Offe, Claus. 1985. "New Social Movements: Challenging the Boundaries of Institutional Politics." Sociological Research 52:817-68.

Pichardo, Nelson A. 1997. "New Social Movements: A Critical Review." Annual Review of Sociology 23 (1): 411-30. https://doi.org/10.1146/annurev.soc.23.1.411.

Precarias a la Deriva. 2004. A La Deriva: Por Los Circuitos de La Precariedad Femenina.

Madrid: TRAFICANTES DE SUEÑOS. http://libros.metabiblioteca.org/handle/001/312.

Sampedro, Víctor, and Josep Lobera. 2014. "The Spanish 15-M Movement: A Consensual Dissent?" Journal of Spanish Cultural Studies,: 1-20.

Sanchez, J.L. Las 10 mareas del cambio. Madrid: Catarata

Standing, Guy. 2011. The Precariat: The New Dangerous Class. New York: Bloomsbury.

Tilly, Charles and Wood, Lesley. 2009. Social Movements, 1768-2012.London: Routledge

Tilly, Charles. 1986. The Contentious French: Four Centuries of Popular Struggle.

Cambridge, MA: Belknap Press.

Tilly, Charles. 1995. Popular Contention in Great Britain, 1758-1834. Cambridge, MA: Harvard University Press.

Tormey, S. (2020) "Visions of a Good Society" in Flesher Fominaya, C. and Feenstra, R. (Eds) The Routledge Handbook of Contemporary European Social Movements. London: Routledge 
Not for circulation-do not cite

Accepted for Karatzogianni, Ferra, Schandorf (eds) Protest Technologies and Media

Revolutions: The Longue Durée Emerald, UK

Touraine, Alain. 1988. Return of the Actor: Social Theory in Postindustrial Society.

Minneapolis: University of Minnesota Press.

Touraine, A. 1983. Solidarity: The Analysis of a Social Movement: Poland, 1980-1981. New York: Cambridge University Press.

Touraine, Alain. 1971. The May Movement: Revolt and Reform. New York: Random House.

Weil, David. 2014. The Fissured Workplace: Why Work Became So Bad for So Many and

What Can Be Done to Improve It. Cambridge, MA: Harvard University Press. 